\title{
The Spread of Psychoactive Substance Use among the Population of the Jewish Autonomous Region
}

\author{
Irina Vorotilkina \\ Department of Service, \\ Advertising and Social Work \\ Sholom-Aleichem Priamursky \\ State University \\ Birobidzhan, Russia \\ btb-irina@ rambler.ru
}

\author{
Ruslan Bazhenov \\ Department of Information \\ Systems, Mathematics and Legal \\ Informatics \\ Sholom-Aleichem Priamursky \\ State University \\ Birobidzhan, Russia \\ r-i-bazhenov@yandex.ru \\ Svetlana Schetinina \\ Department of Physical Culture \\ and Sport \\ Pacific National University \\ Khabarovsk, Russia \\ Shetinina65@mail.ru
}

\author{
Maria Prokopeva \\ Department of Age and \\ Pedagogical Pschology \\ M.K. Ammosov North-Eastern \\ Federal University \\ Yakutsk, Russia \\ prokmary@mail.ru
}

\author{
Natalia Bogachenko \\ Faculty of Philology, History and \\ Journalism \\ Sholom-Aleichem Priamursky \\ State University \\ Birobidzhan, Russia \\ nataliya-bogachenko@yandex.ru
}

\begin{abstract}
One of the most complicated problems of modern Russian society is the spread and use of drugs. The aim of the study is to reveal an attitude of the population of the Jewish Autonomous region to problems of drug addiction. The study was conducted in 2012, 2013 and involved 1,000 respondents per year. We used a technique developed by the State Anti-Drugs Committee of the Russian Federation. The results make it possible to conclude that respondents have an adequate understanding of a real danger of drugs and narcotisation, as well as the process of addiction to psychoactive substances. The major reason for taking or expressing a wish to take drugs is interest or curiosity.
\end{abstract}

Keywords - drug addiction, narcotisation, psychoactive substances, drug control

\section{INTRODUCTION}

Modern Russian society is a complex developing institution. Today, its social structure, social composition of the population, individual and social psychology, system of value orientations of social groups and strata undergo quantitative and qualitative changes. They are characterized by both positive and negative orientations, which generate social dysfunctions, pathology, deviations in the development of the society as well as individuals. One of the most complicated problems of modern Russian society is the spread and use of drugs. Although narcotism is traditionally viewed as a relatively common, statistically stable social phenomenon consisting in taking drugs by some part of the population, it should be recognized that it has caused an acute problem in the country in recent years.
Despite the long history of attempting to control the spread of drugs in Russia, the government control in this sphere is characterized by the absence of a consistent and integrated methodological approach to forming anti-drug policy. Its goals and objectives declared by the legislation, Federal and regional programmes are not factually based. They do not often suggest operationalized solutions, are not perceived and understood by key experts and ordinary employees of social institutions responsible for drug control in their professional activities. The reaction of the society to the existing anti-drug policy is determined by its inefficiency. The majority of the population and representatives of the main 'risk' groups do not know about it or they consider it to be inadequate.

Hence, one of the urgent social problems of the modern society is a high frequency of drug addiction. That is why it is extremely important to identify users of psychoactive substances in time, since the spread of drug addiction threatens both the health of different population groups and the social stability of the society. This situation seriously threatens the economy and demography both of Russia and the world.

The study of extensive literature on the subject has shown that there are scientific publications providing an analysis of illicit drug trafficking and drug addiction in the world. G. M. Muza et al. [1], C. C. Silva et al. [2], A.Yu. Abramov [3].

A serious threat and danger of drug trafficking and drug addiction to the area can be seen in different publications all over the world, e.g. Saxony - K. Voigt et al. [4]; Austria - G. Pakesch al. [5]; Africa - W. Acuda al. [6]; Russia - E. Potapchik and L. Popovich [7], E. A. Koshkina [8]; Spain - B. Rivera al. [9]; Japan - R. Kikura-Hanajiri et al. [10]; China - L. 
Lu and X. Wang [11]; Vietnam - T. Vuong et al. [12]; Spain M. Cañedo and E. Moral [13].

Experts note that the problem of drug trafficking and drug addiction has the most negative impact on the individual and public health of the population, significantly increasing health care spending, posing a threat to the intellectual, human, defence potential of the country: N. Bobrova et al. [14], M. Ma et al. [15], J. S. Melo et al. [16], A.Yu. Abramov [3].

All this makes the problem of the use of psychoactive substances among different population groups actual and requires taking measures at the country level to reduce this threat. The Strategy of the Russian Federation National AntiDrug Policy until 2020 was approved by the decree of the President of the Russian Federation of 09.06.2010 No. 6901. This document contains the information about the modern drug situation in Russia, an expansion in the number of drugs, psychoactive substances or their analogues, which cause great harm to the security and economy of the country, human health [3].

The results of different researches allow stating an increasing role of drug trafficking in Russia, negative consequences of drug addiction as a threat to national security. These scientific works identify causes, factors and conditions for the spread of illicit drug use among different population groups [3].

If we analyse the history of the issue, it should be noted that since the end of the 20th century, researchers have been greatly interested in studying a problem of youth narcomania. Authors establish a connection between this problem and an economic crisis, a rise in poverty, an increase in the number of families at risk, a growth of street children in the country. Statistics shows that in Russia by the beginning of the XXI century $60 \%$ of drug users have been young people aged 18 to 30 [3].

In 2010, international experts estimated that about 250 million people, or 5 percent of the world's adult population aged 15 to 64, had used any illicit drug at least once.

In the United States, at least half of school graduates are familiar with drugs (J. Brook [17]; D. B. Clark [18]). A review of population studies in the United States shows that American schoolchildren have begun to try drugs and alcohol since they are ten and this process reaches its peak when they are 14-15 years old (T. J. Dishion and L. Loeber [19]; R. Pandina and V. Johnson [20]; E.M. Ossiander [21]).

In Europe, for example, in Finland, 10\% of the adult population has used drugs at least once in their life, and in Denmark and England, the proportion is $25 \%$ and $30 \%$ respectively. In Europe as a whole, this number fluctuates around 20\% (Belgium, Germany, Spain, Ireland and the Netherlands). Young people use drugs twice as much as the older generation (B. Hibell [22]; J. B. Janin et al. [23]; L. Degenhardt et al. [24]; M. Nilson et al. [25]; I. Lander [26]).

The study of the problem of the spread of psychoactive substances among adolescents is of a particular interest. This is reflected in the works of H. Küfner [27]. C. C. Silva et al. [2]. The study among elderly people is done in the works of $\mathrm{L}$. Simoni-Wastila and H. K. Yang [28]. Gender differences in the practice of psychoactive substance use are presented in the works of R. Zahnow et al. [29].

\section{METHODS}

We conducted a sociological study in order to identify a society narcotisation level and a population's attitude to the problems of narcomania. Monitoring methods, developed by the State Anti-Drugs Committee of the Russian Federation were used.

The research was carried out in the Centre for Social and Psychological Assistance to Families and Youth (Birobidzhan). The detailed studies were conducted in the districts of the Jewish Autonomous region in 2012 and 2013.

1,000 respondents were involved in the survey per year.

The data was processed by using specialized statistical software SPSS 17.0 complex.

During the sociological research, a unified basic (typical) sociological questionnaire was used for all territorial entities of the Russian Federation.

At the preparatory stage, study areas were identified, a sample was calculated according to which a population survey was conducted, and a number of technical procedures were carried out. At this stage, we developed a research programme, which included a description of the problem situation, a definition of the research problem, the object and the subject of the research, a choice of goals and objectives, a development of a common concept and a technique for data collection and analysis, a development of tools.

Data processing. After completing the field phase of the study, we used a number of technical procedures such as rejection and coding of questionnaires, data entry, etc. They were aimed at processing and systematizing the data and creating an array of initial information, which was necessary for carrying out an analysis in accordance with the objectives.

Analytical phase. This stage allowed us to generalize, analyse the data and develop recommendations. At this stage, we analysed the structure of the phenomenon, searched and determined social patterns, identified cause-and-effect, component and functional relationships.

\section{RESULTS AND DISCUSSION}

In accordance with the characteristics of the region population, the respondents are divided into different age groups (Table 1).

TABLE I. DISTRIBUTION OF RESPONDENTS BY AGE GROUPS, 2013

\begin{tabular}{|c|c|}
\hline Age Category & Percentage of Respondents \\
\hline $12-15$ & 8.8 \\
\hline $16-20$ & 9.2 \\
\hline $21-25$ & 8.4 \\
\hline $26-30$ & 10.5 \\
\hline $31-35$ & 12.1 \\
\hline $36-45$ & 17.1 \\
\hline $46-55$ & 15.8 \\
\hline $56-65$ & 9.3 \\
\hline 66 and older & 4.8 \\
\hline
\end{tabular}


Refused to answer

4

Thus, the respondents of the region are represented by all age groups. It should be noted that the distribution of the respondents by age characteristics corresponds to the structure of respondents in 2012.

$39 \%$ of the respondents are men, $61 \%$ are women.

The distribution of the respondents according to education levels is presented in Table 2.

TABLE II. DISTRIBUTION OF RESPONDENTS BY EDUCATION LEVELS, 2013

\begin{tabular}{|c|c|}
\hline Education & Percentage of Respondents \\
\hline Incomplete Secondary & 16.2 \\
\hline Secondary General & 12.2 \\
\hline Secondary Vocational & 30.9 \\
\hline Higher & 31.1 \\
\hline Refused to answer & 9.6 \\
\hline
\end{tabular}

The distribution of the respondents by social status and occupation is shown in Table 3.

TABLE III. DISTRIBUTION OF RESPONDENTS BY SOCIAL STATUS AND OCCUPATION, 2013

\begin{tabular}{|c|c|}
\hline Social Status and Occupation & $\begin{array}{c}\text { Percentage of } \\
\text { Respondents }\end{array}$ \\
\hline Pupil & 13.1 \\
\hline Student of Vocational Technical School & 2.1 \\
\hline $\begin{array}{c}\text { Student of Secondary Specialized Educational } \\
\text { Institution }\end{array}$ & 1.3 \\
\hline Workman & 19.7 \\
\hline Secondary Vocational Education Employee & 16 \\
\hline Higher Education Employee & 20.7 \\
\hline Engineering Technician & 3.1 \\
\hline Leader Personnel & 3.5 \\
\hline University student & 1.2 \\
\hline Retiree & 5.8 \\
\hline Unemployed & 2.2 \\
\hline Other Occupations & 1.5 \\
\hline Refused to answer & 9.8 \\
\hline
\end{tabular}

The respondents estimated the financial status of their families as high - $4 \%$; above average $-7.3 \%$; average - 50.6\%; below average - $23.8 \%$; low $-9.3 \%$; not answered $-5.0 \%$.

With regard to social and professional affiliation, the sample included such categories of citizens, representing the main groups by social status and occupation, as schoolchildren, students of vocational technical schools, students of secondary specialized educational institutions, workmen, secondary vocational education employees, higher education employees, engineering technicians, leader personnel, university students, unemployed people, and retirees.

Thus, the sample at large within the declared statistical error corresponds to the total population, i.e. the population of the Jewish Autonomous region (JAR). Accordingly, the results of the survey can be considered representative for all its residents.
As a result of the data processing, it is determined that the population of the JAR notes the problems that need to be solved in the first turn, namely a poor quality of roads; alcoholism; unemployment; a poor quality of medical care; a bad condition and high prices of housing services and utilities; lack of housing; drug addiction; crime. The percentage of respondents indicating such a situation is given in Table 4.

TABLE IV. THE SURVEY RESULTS OF JAR POPULATION ABOUT THE PROBLEMS THAT NEED TO BE SOLVED IN THE FIRST TURN

\begin{tabular}{|c|c|c|}
\hline \multirow{2}{*}{$\begin{array}{c}\text { The Problems that Need to Be } \\
\text { Solved in the First Turn }\end{array}$} & \multicolumn{2}{|c|}{ Percentage of Respondents } \\
\cline { 2 - 3 } & $\mathbf{2 0 1 3}$ & $\mathbf{2 0 1 2}$ \\
\hline Poor Quality of Roads & 75.0 & 72.3 \\
\hline Alcoholism & 65.8 & 65.1 \\
\hline Unemployment & 60.3 & 60.2 \\
\hline Poor Quality of Medical Care & 57.2 & 59.4 \\
\hline $\begin{array}{c}\text { Bad Condition and High Prices of } \\
\text { Housing Services and Utilities }\end{array}$ & 51.8 & 51.6 \\
\hline Drug Addiction & 43.7 & 41.6 \\
\hline Lack of Housing & 43.2 & 46.6 \\
\hline Crime & 32.1 & 33.9 \\
\hline
\end{tabular}

It should be noted that according to the respondents, the situation with drug addiction in the whole region in 2013 is the $6^{\text {th }}$ in the ranking of the importance of social problems.

Health has the lowest value for young people, which is not an encouraging factor in fighting against the use of drugs among schoolchildren. At the same time, health is a priority for older respondents, including students of secondary specialized and higher education institutions.

The involvement of young people and population on the whole into something interesting is an important aspect of preventing narcomania. Nevertheless, there is a high number of negative answers about the availability of opportunities for spending free time in a city / village, both in the region (64\% of the respondents) and in different districts. The most negative estimates of a possibility of spending free time are given in Obluchensky district, where $82.2 \%$ of the respondents say about the lack of such opportunities. This indicates that there are no places to spend free time or they are in bad condition.

The analysis of distributing responses about the attitude towards drug abuse among separate age groups shows that the vast majority of pupils, students, workmen, employees, pensioners, and unemployed people have a negative attitude to narcomania. At the same time, a small percentage of schoolchildren and students allegedly indifferent to this problem cause some alarm.

All groups of the respondents consider the spread of drug addiction quite tangible. The highest percentage of the respondents express such an opinion that drug addiction, of course, is a common practice in a town / village in which they live, but no more than in other villages. About $80 \%$ of the respondents of all ages note that nowadays it is quite easy to get drugs (the total number of answers 'relatively easy' and 
'very easy') and only $9.2 \%$ (10.3\% in 2012) reply that it is difficult to get drugs. We should note that there is the biggest number of positive answers to a question of availability of drugs in Birobidzhan, Obluchensky, Smidovichsky and Leninsky districts. From the point of view of the respondents of all ages, nightclubs ( $44.1 \%$ of the answers), apartments $(43.8 \%)$, discos $(36.9 \%)$ are the main places where people can buy drugs.

The awareness of places where drugs are purchased is a significant risk factor for narcotisation. Another risk factor is a presence of young people who use drugs in the social circle. About one third of the respondents $(31 \%)$ say that among their friends there are people who use drugs or they know a lot of people who use drugs. At the same time, about $50 \%$ of university students and workmen say that among their acquaintances there are people who use drugs.

About a third of the respondents $(28.7 \%)$ note that they have ever been offered to take drugs in their lives. At the same time, the share of the respondents who answer positively to the question is the same in all districts of the region (from $25.6 \%$ of positive answers in Birobidzhan to $35 \%$ in Leninsky and Smidovichsky districts). The hypothetical involvement of young people in drug consumption is unsurprisingly very high. Thus, $26 \%$ of schoolchildren, $34 \%$ of students of secondary vocational educational institutions, $62 \%$ of university students were offered to take drugs. This situation indicates the intense involvement of narcotisation risk factors in social relations of the respondents, first of all at the microsocial level.

Nowadays, the problem of drug addiction among young people is very important. Drug addiction and drug-related crime decrease the security level of Russia. Every day drugs become cheaper and more available. The age of drug users lowers. Drug addiction leads to such disastrous consequences as serious and incurable diseases, mental deteriorations, fatal outcome, and rising crime.

The causes of drug use are divided into three groups, namely psychological, social and physiological.

Psychological causes are family problems (lack of parental love, overprotection, self-indulgence, moral and physical violence); curiosity and fashion trend to use drugs; opposition to family and social principles; self-dissatisfaction, fear, boredom, lack of confidence in oneself and his/her future, achieving his/her popularity in the social circle.

Social causes are a crisis of values in the society; influence of Western culture; social environment; high level of immorality in the society; insufficient promotion of healthy lifestyle.

Physiological causes are anxiety; fear; depression; emotional stress; impulsive obsession.

Drug abuse leads to such social consequences as a loss of friendly and family relations, problems with law enforcement agencies and plenty of health problems. Moreover, drugaddicted young people face other more serious consequences such as HIV and AIDS, viral hepatitis B and C, overdose, suicide.
Today, the problem of drug addiction is, first of all, a problem of the individual, which affects the whole society. If we do not understand what makes a person to take drugs, then it will not be easy to overcome the problem of drug addiction. To do this it is necessary to organize and conduct specialized social and diagnostic work at all levels.

The results of the sociological survey make it possible to conclude that the respondents have an accurate impression of the real danger of drugs and narcotisation, as well as a process of getting used to drugs, i.e. people become addicted after the first use. According to the respondents, the factors limiting drug consumption are negative attitude to drug use, early death, a risk of HIV infection and viral hepatitis B and C. It is significant that a disproportionately lesser degree of the respondents are afraid of the consequences, namely to become unwanted for the society, and end up in jail.

In the respondents' opinion, among the measures that need to be taken to solve the problems of drug addiction, such measures as imposing severer penalties for drug offenses $(50 \%$ of the answers), compulsory treatment of drug addicts (49.3\%), working with young people more regularly, assistance in socialization $(35.7 \%)$ are high-priority.

At the same time, the majority of young people (schoolchildren, students) speak in favour of the compulsory treatment of drug addicts, older respondents (workmen, employees) also say about the need to impose severer penalties for drug offenses and work with young people more regularly, pensioners say that experts in narcomania and law enforcement officials should give public lectures on the problem of narcomania.

Among the causes of drug addiction there are excessive freedom, unemployment of young people $(57 \%$ of the respondents), moral degradation of the society, permissiveness (50\%), dissatisfaction with life, social deprivation (43.8\%), unemployment, economic problems (32.9\%). Among the causes of drug addiction young people identify dissatisfaction with life, social deprivation, workmen and employees give prominence to permissiveness, excessive freedom, unemployment of young people.

To the direct question about having their own experience of drug use $8.1 \%$ of young respondents respond that they either want to try, or have already tried 1-2 times, or use constantly. At the same time, taking into account the character of answers to such direct questions, it is clear that these figures do not correspond to the real situation.

But according to the obtained data we have already been able to make a conclusion that every twelfth person in the region is at risk of involvement in drug consumption or use drugs. The socio-demographic profile of drug users according to some characteristics is such as men (85.7\% of the users); representatives of the age groups 14-20 and 31-65; people with incomplete secondary education; workmen (42.9\%), pupils $(14.3 \%)$, students of vocational educational institutions (28.6\%), unemployed people $(14.2 \%)$; middle-income people $(57.1 \%)$ and below. 
From the point of view of socio-psychological characteristics, drug users are people who value their physical and mental health at low rate.

The dominant reason for using or wanting to use drugs is interest or curiosity.

Most respondents who answer positively to the question about the consumption of drugs used them only once, mainly in the form of smoking (cannabis).

Among the reasons for taking drugs there are such as a desire to conform to a certain social level, for the company, to 'belong' to the group, follow the crowd; accessibility, that is drugs are not very expensive and not difficult to buy; confidence that the selected drugs are less harmful, and it is easy to stop taking them. The majority of consumers either buy drugs or "help themselves". Among the channels of getting drugs the immediate environment dominates, friends / acquaintances deal in drugs. Most drug users pay the money which they earn themselves. Respondents refuse to give an answer about the amount they spend on buying drugs. According to the answers of 4 respondents, they spend an average of 3,700 roubles a month on purchasing drugs, and monthly expenses vary from 300 to 10,000 roubles.

Two drug-using respondents replied that they had received treatment and rehabilitation after treatment.

About half of the respondents $(51 \%)$ believe that if a person has a real desire it is possible to cure drug addiction on his own. At the same time, the need for compulsory treatment is noted by $14.1 \%$ of the respondents and $20.8 \%$ of the respondents note that treatment from drug addiction is almost impossible.

In general, less than 30 percent of the population is aware of forms and methods of drug prevention, and the majority of the population found it difficult to enumerate events against drug use. From the point of view of the respondents, the most effective and interesting events are speeches of former drug addicts, anti-drug advertising on television, the press, radio, thematic programmes and films on television, lectures and conversations in educational institutions.

In this regard, such measures appear to be appropriate for optimizing preventive activities as an intense and systematic involvement of specialists, namely doctors, psychologists, representatives of the Federal Drug Control Service of the Russian Federation for giving lectures, seminars, trainings both to students and their parents in order to develop a parents' proper understanding of the problem, form an adequate, nonintrusive, adapted approach when discussing this issue with their children.

The regional state budgetary institution of additional education 'Centre 'MOST' (Birobidzhan) has quite a rich experience in this sphere. This institution has been actively working with young people since 1992. It exercises the rights of family and youth, provides social and legal protection, support and strengthening of psychological health of the population in the territory of the Jewish Autonomous region. It offers consultations for free, provides practical, psychological, psychotherapeutic, narcological assistance. Families, individuals, institutions that educate and train underage children get assistance and support in the Centre.

A special role is assigned to educational activity. Lectures, training seminars, lessons on the prevention of drug dependence are held for the population of the region. People acquire skills for a healthy life. Participants of seminars and lectures are not only young people, but also teachers of secondary and additional educational institutions, as well as cultural professionals, libraries, who carry out their activities in the city of Birobidzhan. These forms of work are used to improve the competence level of specialists in preventing narcomania, adolescents' desocialization in conditions of informal interaction, as well as to exchange experience. The themes of the seminars that are the most in-demand are 'Peculiarities of Adolescents' Desocialization in Conditions of Informal Interaction', 'The Popularity of Psychoactive Substances Consumption among Adolescents and Youth of the Jewish Autonomous Region', 'Psychological and Behavioral Disorders Developing because of the Use of Drugs and Psychoactive Substances', 'Prevention of Drug-dependent Behavior in the Youth Environment as a Basis of Maintaining Younger Generation Health', 'Epidemiology of Drug Dependence', etc.

Practical activities aimed at desocialization of adolescents are also of great interest. Such forms of work are widely used as sports, recreation and volunteer activities, work of core groups of children's school organizations, 'Debate' intellectual game, 'Trust' public reception office, project activities and others. The theoretical and practical knowledge gained during workshops help refreshing the work on the organization of extracurricular activities of adolescents, contributing to their positive socialization.

The Internet lesson on drug problems has proven to be an effective means of the anti-drug campaign which demonstrates the negative aspects of drug consumption from all the sides, provides new forms and methods of struggling against narcomania, develops psychological resistance of children and young people to drug use. The objectives of the Internet lesson are to present the materials of the Internet lesson available on the official website of the Federal Drug Control Service of the Russian Federation to students (pupils, students of primary and secondary vocational educational institutions). The Internet lesson helped to teach parents, teaching staff of educational institutions, and volunteers how to identify early signs of drug use and to implement anti-drug preventive measures.

\section{CONCLUSION}

Drug addiction is a problem of the person which affects all the society. It is an initiator of such social consequences as damage of friendly and family relations, problems with the police; deterioration of health.

In society, there is an adequate understanding of the real danger of drugs and narcotisation, addiction after the first use.

High-priority measures to combat drug addiction are compulsory treatment of drug addicts, imposing severer penalties for drug offenses, working with young people more regularly, assistance in socialization. 
The reasons for the spread of narcomania are youth unemployment, moral degradation of society, permissiveness, dissatisfaction with life, social deprivation, unemployment, economic problems. The dominant reason for using or wanting to use drugs is interest or curiosity. At the same time, many respondents (more than $50 \%$ ) believe that if a person has a real desire it is possible to cure drug addiction on his own, although they allow the possibility of compulsory treatment.

The most effective measures to combat drug addiction are speeches of former drug addicts, anti-drug advertising, thematic programs and films, lectures and conversations in educational institutions.

\section{REFERENCES}

[1] G. M. Muza, H. Bettiol, G. Muccillo, and M. A. Barbieri, "The consumption of psychoactive substances by adolescents in schools in Ribeiräo Preto, SP (Brazil). I--Prevalence of consumption by sex, age and substance," Revista de saude publica, vol. 31, pp. 21-29, 1997.

[2] C. C. Silva, M. C. O. Costa, R. C. D. Carvalho, M. T. R. Amaral, N. L. D. A. Cruz, and M. R. D. Silva, "Initiation and consumption of psychoactive substances among adolescents and young adults in an AntiDrug Psychosocial Care Center," Ciencia \& saude coletiva, vol. 19, pp. 737-745, 2014.

[3] A.Yu. Abramove, Improving the mechanism for regulating the circulation of drugs and psychotropic substances in the Russian Federation (Sovershenstvovaniye mekhanizma regulirovaniya oborota narkoticheskikh sredstv i psikhotropnykh veshchestv v Rossiyskoy Federatsii). Thesis of Grand PhD in Medicine, Moscow, 316 p., 2015 [in Rus.]

[4] K. Voigt, S. Twork, D. Mittag, A. Göbel, R. Voigt, J. Klewer, and A. Bergmann, "Consumption of alcohol, cigarettes and illegal substances among physicians and medical students in Brandenburg and Saxony (Germany)," BMC health services research, vol. 9, pp.219, 2009.

[5] G. Pakesch, N. Liomer, E. Rasinger, and H. Katschnig, "The prevalence of psychoactive drug intake in a metropolitan population," Medicine \& Law, vol. 8, pp.63-72, 1989.

[6] W. Acuda, C. J. Othieno, A. Obondo, and I. B. Crome, "The epidemiology of addiction in Sub- Saharan Africa: A synthesis of reports, reviews, and original articles," The American journal on addictions,vol. 20, pp. 87-99, 2011.

[7] E. Potapchik, and L. Popovich, "Social cost of substance abuse in Russia," Value in Health Regional Issues, vol.4, pp.1-5, 2014.

[8] E. A. Koshkina, "The prevalence of the use of narcotics and other psychoactive substances in Russia today," Zhurnal mikrobiologii, epidemiologii, i immunobiologii, vol.4, pp.15-19, 2000.

[9] B. Rivera, B. Casal, and L. Currais, "The social cost of illicit drugs use in Spain," International Journal of Drug Policy, vol. 44, pp. 92-104, 2017.

[10] R. Kikura-Hanajiri, N. Uchiyama, and Y. Goda, "Survey of current trends in the abuse of psychotropic substances and plants in Japan," Legal Medicine, vol. 13, pp. 109-115, 2011.

[11] L. Lu, and X. Wang, "Drug addiction in China," Annals of the New York Academy of Sciences, vol. 1141, pp. 304-317, 2008.

[12] T. Vuong, R. Ali, S. Baldwin, and S. Mills, "Drug policy in Vietnam: A decade of change?" International journal of drug policy, vol.23, pp. 319326, 2012.
[13] M. Cañedo, and E. Moral, "Risky pleasures and drugged assemblages: Young people's consumption practices of AOD in Madrid," International Journal of Drug Policy, vol.49, pp. 102-108, 2017.

[14] N. Bobrova, T. Rhodes, R. Power, R. Alcorn, E. Neifeld, N.Krasiukov, and S. Maksimova, "Barriers to accessing drug treatment in Russia: a qualitative study among injecting drug users in two cities," Drug \& Alcohol Dependence, vol. 82, pp. 57-63, 2006.

[15] M. Ma, S. Liu, and J. Li, "Does media coverage influence the spread of drug addiction?" Communications in Nonlinear Science and Numerical Simulation, vol. 50, pp.169-179, 2017.

[16] J. S. Melo, R. S. Garfein, K. Hayashi, M. J. Milloy, K. DeBeck, S. Sun, and D. Werb, "Do law enforcement interactions reduce the initiation of injection drug use? An investigation in three North American settings," Drug \& Alcohol Dependence, vol. 182, pp. 67-73, 2018.

[17] J. Brook, "The risks for late adolescence of early marijuana use," American Journal of Public Health, vol.89. pp.1549-1554, 1999.

[18] D.B. Clark, "Childhood risk categories for adolescent substance involvement: a general liability typology," Drug \& Alcohol Dependence, vol. 77, p.13-21, 2005.

[19] T.J. Dishion, and L. Loeber, "Adolescent marihuana and alcohol use: the role of parents and peers revisited," The American journal of drug and alcohol abuse, vol.11, pp.11-25, 1985.

[20] R. Pandina, and V. Johnson, "Serious alcohol and drug problems among adolescents with a family history of alcoholism," Journal of Studies on Alcohol, vol. 51. p.278-282, 1990

[21] E.M. Ossiander, "Volatile substance misuse deaths in Washington State, 2003-2012," The American journal of drug and alcohol abuse, vol.41, pp.30-34, 2015.

[22] B. Hibell. The ESPAD report - Alcohol and other drugs among students in 30 European countries. Stockholm, Swedish Council for Information on Alcohol and Other Drugs. Council of Europe, 2000

[23] J. B. Janin, Y. Francois, and H. Schmid, "Konsum psychoaktiver Substanzen" in H. Schmid, E.N. Kuntsche, and M. Delgrande, Anpassen, ausweichen, aufl ehnen? Fakten und Hintergründe zur psychosozialen Gesundheit und zum Konsum psychoaktiver Substanzen von Schülerinnen und Schülern. Bern: Haupt., 2001, pp. 347-391.

[24] L. Degenhardt, C. Coffey, J. B. Carlin, W. Swift, E. Moore, G.C. Patton, "Outcomes of occasional cannabis use in adolescence: 10-year followup study in Victoria, Australia The British Journal of Psychiatry, vol. 196. pp.290-295, 2010.

[25] M. Nilson, D. Lopez, C. Robertson, S.Martel, R. Saimon, and P. Griffiths, "European monitoring centre for drugs and drug addiction information centre on drugs in Europe," [Yevropeyskiy tsentr monitoringa narkotikov i narkomanii - informatsionnyy tsentr po narkotikam v Yevrope] Narcology, vol.9, pp. 20-27, 2010 [in Rus.]

[26] I. Lander, Gender, Aging and Drug Use: A Post-structural Approach to the Life Course," British Journal of Criminology. vol.55. pp. 270-285, 2015.

[27] H. Küfner, "Epidemiologie des Substanzkonsums und der Suchterkrankungen in Deutschland," BundesgesundheitsblattGesundheitsforschung-Gesundheitsschutz, vol. 53, pp. 271-283, 2010.

[28] L. Simoni-Wastila, and H. K. Yang, "Psychoactive drug abuse in older adults," The American journal of geriatric pharmacotherapy, vol. 4, pp.380-394, 2006.

[29] R. Zahnow, A. R. Winstock, L. J. Maier, J. Levy, and J. Ferris, "Injecting drug use: Gendered risk," International Journal of Drug Policy, vol. 56, pp.81-91, 2018. 